Ambiente \& Água - An Interdisciplinary Journal of Applied Science
ISSN 1980-993X - doi:10.4136/1980-993X
www.ambi-agua.net
E-mail: ambi.agua@gmail.com

\title{
Rainfall trends for the State of Paraná: present and future climate
}

\author{
ARTICLES doi:10.4136/ambi-agua.2258 \\ Received: 21 Mar. 2018; Accepted: 18 Dec. 2018 \\ Luciana Espindula de Quadros ${ }^{*}$ (D) Eloy Lemos de Mello ${ }^{2}$;
Benedito Martins Gomes ${ }^{2}$; Fernanda Cristina Araujo \\ ${ }^{1}$ Instituto Federal do Paraná (IFPR), Foz do Iguaçu, PR, Brasil \\ E-mail: luciana.quadros@ifpr.edu.br \\ ${ }^{2}$ Universidade Estadual do Oeste do Paraná (UNIOESTE), Cascavel, PR, Brasil \\ E-mail: eloymello@gmail.com, benedito.gomes@unioeste.br, fer.crisaraujo@yahoo.com.br \\ *Corresponding author
}

\begin{abstract}
This paper analyzes the variability and the precipitation trend of the State of Paraná, in Brazil. For that, monthly precipitation data belonging to 24 precipitation stations in a 30-year period (1980-2010) were analyzed and they were compared with projections of precipitation for the years 2016-2050. These data were simulated by Eta/Miroc5 for RCP 4.5 (Representative Concentration Pathways) from the Center for Weather Forecasting and Climate Studies CPTEC/INPE and the historical data of precipitation were taken from National Water Agency (ANA). The Mann-Kendall non-parametric test and the Sen's slope estimator were applied to detect trends and magnitudes, respectively. The MannWhitney test was used to compare the median of the historical series (1980-2010) with the simulated series (2016-2050) and the comparison of the means between the two series was performed by Test $t$. The results draw attention to the great variability and significant changes in the monthly average rainfall that may occur, if the climate change scenarios that were considered become a reality in the near future.
\end{abstract}

Keywords: climate changes, climate models, precipitation variability.

\section{Tendência da precipitação no Estado do Paraná: clima presente e futuro}

\section{RESUMO}

O objetivo deste artigo é analisar a variabilidade e a tendência de precipitação do Estado do Paraná, Brasil. Para isso, foram analisados os dados de precipitação mensal pertencentes a 24 estações de precipitação pluviométrica em um período de 30 anos (1980-2010) e foi comparado com as projeções futuras sobre a precipitação para os anos de 2016-2050. Estes dados foram simulados por Eta/Miroc5 para RCP 4.5 (Caminhos Representativos de Concentrações) proveniente do Centro de Previsão de Tempo e Estudos Climáticos CPTEC/INPE e os dados históricos de precipitação utilizados foram da Agência Nacional de Águas (ANA). O teste não-paramétrico de Mann-Kendall e o estimador de Sen foram aplicados para detectar tendências e sua magnitude, respectivamente. O teste de Mann-Whitney foi usado para comparar a mediana da série histórica (1980-2010) com a mediana da série simulada (2016-2050) e a comparação das médias entre as duas séries foram realizadas pelo Test $t$. Os resultados chamam atenção para a grande variabilidade e mudanças significativas na 
precipitação média mensal que poderá ocorrer, se os cenários de mudanças climáticas que foram consideradas se tornarem uma realidade no futuro próximo.

Palavras-chave: modelos climáticos, mudanças climáticas, variabilidade de precipitação.

\section{INTRODUCTION}

Among the many effects that climate variability could be responsible for, a major concern is the imminence of a possible increase in the occurrence of extreme events around the globe, which could directly affect the human population and other living organisms. Several studies and investigations have been conducted in order to identify which elements are causing such impacts and what are their intensities and frequencies of occurrence (Zandonadi and Acquaotta, 2016).

According to the Brazil Panel on Climate Change (PBMC, 2013), some regions of Brazil may experience changes in temperature and rainfall with global warming. Intensifications of severe events should occur, causing severe impacts in cities and areas vulnerable to climate change. The possible impacts of these changes will occur at different scales, according to the specific characteristics of each region of Brazil. It is necessary to know and map the vulnerabilities of Brazilian regions to identify, propose and implement adaptation measures.

Among all the variables, the precipitation is one of the most important meteorological variables which can impact the occurrence of drought or flood. Analysis of precipitation data yields relevant information which can be used to improve water management strategies, protect the environment, agricultural production planning or impact economic development of a certain region (Gocic and Trajkovic, 2013).

In recent years, scientists worldwide have compared and analyzed precipitation trends, but precipitation isn't the only focus; other meteorological parameters have also been studied for adaptation and mitigation strategies for potential future changes. The Global Climate Models (GCMs) and dynamical downscaling using Regional Climate Models (RCMs) are the main tools of the analyses aimed at assessing what climate we are likely to have in the near- and notso-near future (Marengo et al., 2012). According to Adam and Collischonn (2013), the GCMs take into account the behavior of climate compartments (atmosphere, oceans, vegetation, soils, etc.) and their interactions in a quantitative model (numerical), allowing the simulation of probable climate evolution projections for various scenarios of emissions of greenhouse gases. These simulations have resulted in four pathways being adopted by the IPCC, denominated "Representative Concentration Pathways" (RCPs). The four RCPs included one mitigation scenario leading to a very high baseline emission scenarios (RCP 8.5), two medium stabilization scenarios (RCP 4.5/RCP 6.0) and one very low forcing level (RCP 2.6) (Vuuren et al., 2011).

The use of RCMs also contributed to information enhancement, because on a regional scale the information is more accurate and the computational advancement allowed the inclusion of more components and processes in the simulations and spatial resolution of the models, thus increasing their complexity (Marengo et al., 2009). In South America, the Eta Model has been used to provide time forecasts, because this model is able to produce satisfactory results in regions that contain sharp orography, such as the Andeas Mountains (Chou et al., 2011).

Singh and Goyal (2016) analyzed the spatial and temporal variability of precipitation lapse rate and of precipitation extreme indices of the Teesta River catchment, which corresponds to north Sikkim eastern Himalayas. For this, they used series durations observed (1980-2005) and simulated precipitation data sets (2006-2100) simulated by CMIP5 ESM-2 M Model (Coupled Model Intercomparison Project Phase 5 Earth System Model 2), employing three different radiative forcing scenarios Representative Concentration Pathways (RCP). 
In Korea, Kim et al. (2016) researched heat waves associated with climate change using a series of observational data from 1994 to 2012 to deduce the causal factors that affect the number of deaths from heat disorders, because the greater concern is that the steady increase in death rate is expected to be intercepted by more severe events in the future compared to the present period. To simulate future changes in heat wave incidences in Korea for the period from 2013 to 2060, they used data simulated using the Hadley Centre Global Environmental for two RCP scenarios: RCP 4.5 and RCP 8.5.

In the southeast Brazil, a study was done on possible changes in air temperature and the effect of this on coffee beverage quality. Based on climate projections using the Eta/HadCM3 for the period of 2011 to 2100 , the simulation of future changes was possible. The effects of this process on coffee beverage quality were simulated and the results indicated that, in the case of an occurrence of A1B emission scenario, the coffee beverage quality could be affected in this region due to the fact that the flavor may become stronger and unpleasant caused by rising air temperatures (Giarolla et al., 2012).

Therefore, this study sought to use simulations to understand changing trends in different contexts. This paper analyzes the variability and the precipitation trend of the observed precipitation data (1980-2010) and simulated data by Eta/Miroc5 (2016-2050) for RCP 4.5 of the State of Paraná, in Brazil.

\section{MATERIAL AND METHODS}

Monthly precipitation series from 1980 to 2010 from the National Water Agency (ANA) database from 24 precipitation stations in the State of Paraná were used. Figures 1 and 2 represent the spatial distribution of the stations. Data gaps were filled using values from the nearest neighboring observatories. To apply this method, two criteria were established: 1) the correlation (Pearson's r) between the monthly precipitation series from both observatories was required to be higher than 0.7 (Barbosa et al., 2005; Pruski et al., 2004); and 2) the nearest stations were considered, with a maximum distance of $100 \mathrm{~km}$, taking into consideration that Baba et al. (2014) states that the nearest stations are more likely to have similar behaviors with respect to the treated variables (Table 1 ).

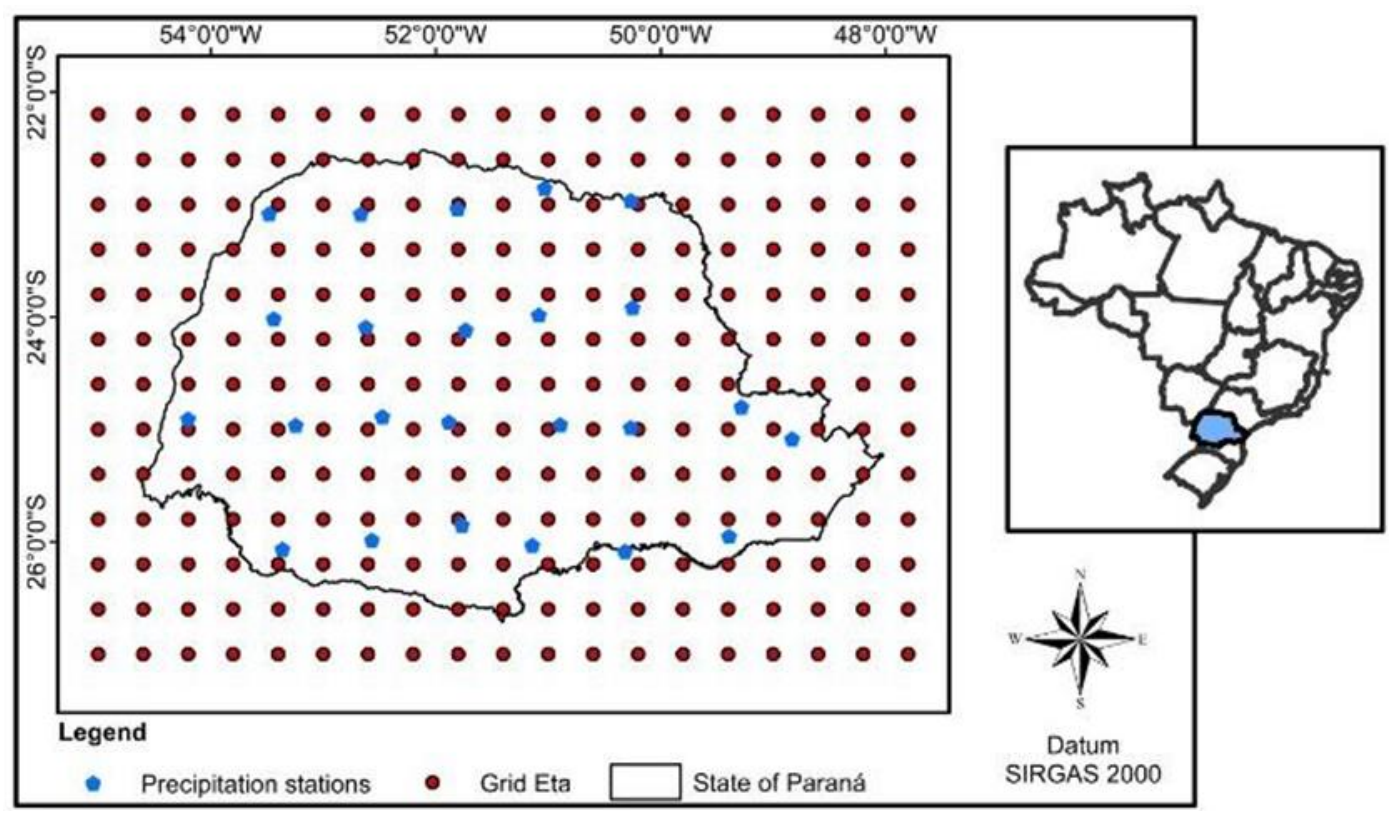

Figure 1. Spatial distribution of the 24 precipitation stations and grid of Eta/MIROC5 model with 824 pixels covering the State of Paraná. 


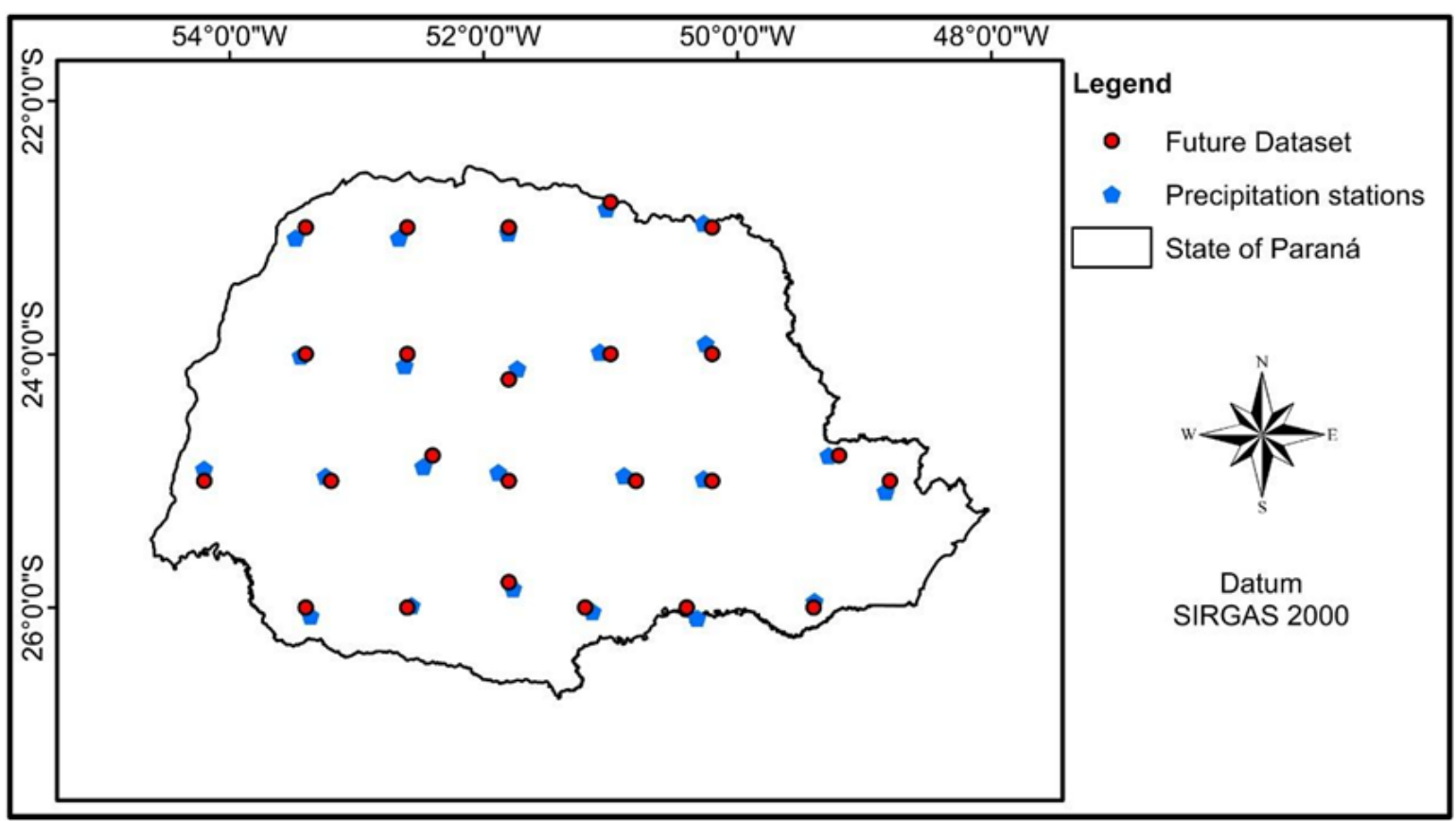

Figure 2. Spatial distribution of the 24 precipitation stations in the State of Paraná and the simulated data set simulated with Eta/MIROC.

In order to detect trends, the Mann-Kendall non-parametric statistical was used in the precipitation series. The series of 1980 to 2010 were put together with the series 2016 to 2050, considering a single series at each point studied. For this, the test statistic $\mathrm{Z}$ was used (Equations $1,2,3$ and 4):

$Z= \begin{cases}\frac{(S-1)}{\sqrt{\operatorname{var}(S)}} & \text { if } S>0 \\ 0 & \text { if } S=0 \\ \frac{(S+1)}{\sqrt{\operatorname{var}(S)}} & \text { if } S<0\end{cases}$

where:

$S=\sum_{i=1}^{n-1} \sum_{j=i+1}^{n} \operatorname{sgn}\left(x_{j}-x_{i}\right)$

$\operatorname{sgn}\left(x_{j}-x_{i}\right)=\left\{\begin{array}{c}+1, \text { if } x_{j}>x_{i} \\ 0, \text { if } x_{j}=x_{i} \\ -1, \text { if } x_{j}<x_{i}\end{array}\right.$

$\operatorname{var}(S)=\frac{n(n-1)(2 n+5)-\sum_{i=1 \ldots m} t_{i}\left(t_{i}-1\right)\left(2 t_{i}+5\right)}{18}$

Where $\operatorname{sgn}\left(x_{j}-x_{i}\right)$ is the sign function, $n$ is the number of data points, $m$ is the number of tied groups and $t_{i}$ denotes the number of observations of the $i$-th tied group. A tied group is a set of sample data having the same value.

Positive values of $\mathrm{Z}$ show increasing trends while negative $\mathrm{Z}$ values indicate decreasing trends. For this study a $5 \%$ significance level was considered. 
Table 1. The information of precipitation stations and simulated data set by RCP scenario 4.5 Miroc5.

\begin{tabular}{|c|c|c|c|c|c|c|c|}
\hline \multirow[b]{2}{*}{ No } & \multicolumn{4}{|c|}{ Historical data } & \multicolumn{2}{|c|}{ Simulated data set } & \multirow{2}{*}{ Distance between them $(\mathrm{km})$} \\
\hline & Stations & Latitude & Longitude & Elevation & Latitude & Longitude & \\
\hline 1 & 2454018 & -24.9061 & -54.2014 & 243 & -25.000 & -54.2 & 10.41 \\
\hline 2 & 2653016 & -26.0644 & -53.3622 & 557 & -26.000 & -53.4 & 8.08 \\
\hline 3 & 2453056 & -24.9628 & -53.2439 & 697 & -25.000 & -53.2 & 6.05 \\
\hline 4 & 2453008 & -24.0147 & -53.4397 & 427 & -23.999 & -53.4 & 4.39 \\
\hline 5 & 2353010 & -23.0817 & -53.4811 & 349 & -22.999 & -53.4 & 12.37 \\
\hline 6 & 2552044 & -25.9833 & -52.5667 & 700 & -26.000 & -52.6 & 3.81 \\
\hline 7 & 2452019 & -24.8858 & -52.4739 & 741 & -24.800 & -52.4 & 12.06 \\
\hline 8 & 2452029 & -24.0906 & -52.6214 & 582 & -23.999 & -52.6 & 10.37 \\
\hline 9 & 2352052 & -23.0831 & -52.6667 & 450 & -22.999 & -52.6 & 11.55 \\
\hline 10 & 2551019 & -25.85 & -51.7667 & 1245 & -25.800 & -51.8 & 6.46 \\
\hline 11 & 2451010 & -24.9333 & -51.8833 & 900 & -25.000 & -51.8 & 11.19 \\
\hline 12 & 2451049 & -24.1144 & -51.7342 & 618 & -24.199 & -51.8 & 11.5 \\
\hline 13 & 2351065 & -23.0403 & -51.8056 & 485 & -22.999 & -51.8 & 4.6 \\
\hline 14 & 2651005 & -26.0306 & -51.1419 & 840 & -26.000 & -51.199 & 6.64 \\
\hline 15 & 2450049 & -24.9575 & -50.8917 & 743 & -25.000 & -50.799 & 10.47 \\
\hline 16 & 2351041 & -23.9831 & -51.0831 & 1011 & -23.999 & -50.999 & 8.73 \\
\hline 17 & 2251039 & -22.8517 & -51.0319 & 370 & -22.799 & -50.999 & 6.47 \\
\hline 18 & 2650005 & -26.0833 & -50.3167 & 770 & -26.000 & -50.399 & 12.36 \\
\hline 19 & 2450021 & -24.9831 & -50.2667 & 950 & -25.000 & -50.199 & 7.08 \\
\hline 20 & 2350041 & -23.9167 & -50.25 & 600 & -23.999 & -50.199 & 10.48 \\
\hline 21 & 2250033 & -22.9653 & -50.2661 & 423 & -22.999 & -50.199 & 7.82 \\
\hline 22 & 2549003 & -25.95 & -49.3931 & 810 & -26.000 & -49.399 & 5.57 \\
\hline 23 & 2449006 & -24.8 & -49.2833 & 270 & -24.800 & -49.199 & 8.52 \\
\hline 24 & 2548040 & -25.0833 & -48.8333 & 670 & -25.000 & -48.799 & 9.86 \\
\hline
\end{tabular}

The Mann-Kendall test allows us to detect statistically significant trends, but does not provide estimates of the steepness of the trend slope. For this reason, the application was complemented by Sen's slope estimator. It is defined as (Equation 5):

$B=M d\left(\frac{x_{i}-x_{j}}{t_{i}-t_{j}}\right)$

Where $\mathrm{Md}$ is the value of median and $x_{i}$ and $x_{j}$ are data values at times $t_{i}$ and $t_{j}(i>j)$, respectively.

The Mann-Kendall statistical test and Sen's slope estimator have often been used to detect trend in hydro-meteorological time series. (Gocic and Trajkovic, 2013; Santos and Fragoso, 2013; Yürekli, 2015).

To determine if there are any statistically significant differences between the medians, the Mann-Whitney test was applied; this the series of 1980 to 2010 was compared with the series 2016 to 2050. The Mann-Whitney test statistics are described as (Equation. 6):

$Z=\frac{w-\frac{n \cdot m}{2}}{\sqrt{\frac{n \cdot m(n+m+1)}{12}}}$

Where $n$ is the historic size series, $m$ is the simulated size series, $w$ is defined as the smaller value of $w_{1}$ and $w_{2}$, where (Equations 7 and 8):

$w_{1}=r_{1}-\frac{n(n+1)}{2}$ 
$w_{2}=r_{2}-\frac{m(m+1)}{2}$

To calculate $r_{1}$ and $r_{2}$, both groups (historic series and simulated series) were put in a single set. Afterwards, numeric ranks were assigned to all the observations. In case of equal numbers, an average of the ranking was made to find out their position. Then, the historical and simulated series were separated again, $r_{1}$ is the sum of the ranks of the historic series and $r_{2}$ is the sum of the ranks of the simulated series.

The null hypothesis is stated as the median of the historic series equals the median of the simulated series. If the p-value were less than or equal to the significance level of 0.05 , the decision will be to reject the null hypothesis. It must be concluded that the difference between the population medians is statistically significant.

The 2-Sample Test $t$ was used to compare the precipitation averages between two independent groups, the historical data and simulated data, and to determine if there is a significant difference between them. The null hypothesis is the difference between the population means $\left(\mu_{1}-\mu_{2}\right)$ equals zero. Rejecting the null hypothesis, it can be concluded that the difference between the population means that it is not equal to, or greater than, or less than the reference value chosen in case zero. The Test $t$ (Equation 9):

$t=\frac{\mu_{A}-\mu_{B}}{\sqrt{S^{2}\left(\frac{1}{n_{A}}+\frac{1}{n_{B}}\right)}}$ where $S^{2}=\frac{\left(n_{A}-1\right) S_{A}^{2}+\left(n_{B}-1\right) S_{B}^{2}}{n_{A}+n_{B}-2}$

In which: $S_{A}^{2}$ and $S_{B}^{2}$ are the variances of precipitation values of historical and simulated data; $\mu_{A}$ and $\mu_{B}$ sample means of precipitation values of historical and simulated data, $n_{A}$ and $n_{B}$ is the length of the series, respectively. If the variances are equal, $S^{2}$ will correspond to the variance of both samples.

\section{RESULTS AND DISCUSSION}

For the period 1980 to 2010 and 2016 to 2050, monthly trends of precipitation were obtained by the Mann-Kendall test, the Sen's slope estimator, the Mann-Whitney Test and the Test $t$ and the results are given in Table 2 .

According the results of the Mann Kendall test, there is a significant trend in monthly precipitation series and this was detected on seventeen points of the twenty-four points at the $5 \%$ significance level, while other points had no significant trends.

The monthly precipitation at fifteen points over the State of Paraná tends to increase until 2050 and two points tend to decrease. The points with increased trend are 6, 7, 9, 10, 12-15, 17 21, 23 and 24. The points with decreased trend are point 2 and point 11 (Table 2).

From 1980 to 2050, the monthly rainfall has been declining at the rate of $0.0605 \mathrm{~mm}$ month $^{-1}$ at point 2 and $0.0369 \mathrm{~mm} \mathrm{month}^{-1}$ at point 11 . The points that have an increasing trend, the rates of raising are $0.0967,0.1307,0.0479,0.1273,0.1642,0.0515,0.1186,0.1641,0.0018$, $0.1612,0.1372,0.0443,0.0319,0.0428,0.0192,0.1896$ and $0.0794 \mathrm{~mm} \mathrm{month}^{-1}$, respectively in points $6,7,9,10,12,13,14,15,17,18,19,20,21,23$ and 24.

Still in Table 2, note the results of the Mann-Whitney test (nonparametric) and t tests (parametric). The test results relate to the use of the statistics at each point comparing the period of 1980 to 2010 and 2016 to 2050. It is observed that, even as with the Mann-Kendall test, seventeen points of the twenty-four points show a trend with a significance level of 5\%, meaning that there is a change in the trend of monthly precipitation in the State of Paraná. Only at point 20 does the Mann-Whitney test differ from the other tests, but at the other points, the Mann-Whitney test and Test $t$ confirm the result of the Mann-Kendall test. 
Table 2. Results of statistical tests trend of rainfall in the State of Paraná.

\begin{tabular}{|c|c|c|c|c|c|c|c|c|c|}
\hline & \multicolumn{2}{|c|}{ Mann-Kendall } & \multirow{2}{*}{$\begin{array}{c}\text { Sen's slope } \\
m m \\
\text { month }^{-1}\end{array}$} & & \multicolumn{2}{|c|}{ Mann-Whitney } & \multicolumn{3}{|c|}{ Test $t$} \\
\hline & $\begin{array}{c}p \text {-value } \\
\text { increasing }\end{array}$ & $\begin{array}{c}p \text {-value } \\
\text { decreasing }\end{array}$ & & & Median & $p$-value & Mean & Increment & $p$-value \\
\hline 1 & 0.501 & 0.498 & 0.0000 & $\begin{array}{l}\text { Hist1 } \\
\text { Fut } 1\end{array}$ & $\begin{array}{l}130.20 \\
121.90\end{array}$ & 0.992 & $\begin{array}{l}142.8 \\
143.4\end{array}$ & $+0.42 \%$ & 0.930 \\
\hline 2 & 0.999 & $0.000 *$ & -0.0605 & $\begin{array}{l}\text { Hist2 } \\
\text { Fut } 2\end{array}$ & $\begin{array}{l}160.80 \\
120.77\end{array}$ & $0.000 *$ & $\begin{array}{c}177 \\
142.2\end{array}$ & $-19.66 \%$ & $0.000^{*}$ \\
\hline 3 & 0.083 & 0.917 & 0.0218 & $\begin{array}{l}\text { Hist3 } \\
\text { Fut } 3\end{array}$ & $\begin{array}{l}153.10 \\
154.92\end{array}$ & 0.204 & $\begin{array}{l}168 \\
178\end{array}$ & $+5.95 \%$ & 0.195 \\
\hline 4 & 0.243 & 0.757 & 0.0089 & $\begin{array}{l}\text { Hist4 } \\
\text { Fut } 4\end{array}$ & $\begin{array}{l}122.65 \\
121.91\end{array}$ & 0.584 & $\begin{array}{l}136.6 \\
140.1\end{array}$ & $+2.56 \%$ & 0.590 \\
\hline 5 & 0.153 & 0.846 & 0.0137 & $\begin{array}{l}\text { Hist5 } \\
\text { Fut } 5\end{array}$ & $\begin{array}{l}115.00 \\
121.00\end{array}$ & 0.256 & $\begin{array}{l}136.8 \\
143.9\end{array}$ & $+5.19 \%$ & 0.295 \\
\hline 6 & $0.000 *$ & 1.000 & 0.0967 & $\begin{array}{l}\text { Hist6 } \\
\text { Fut } 6\end{array}$ & $\begin{array}{l}153.15 \\
207.08\end{array}$ & $0.000 *$ & $\begin{array}{l}169 \\
227\end{array}$ & $+34.32 \%$ & $0.000^{*}$ \\
\hline 7 & $0.000 *$ & 1.000 & 0.1307 & $\begin{array}{l}\text { Hist7 } \\
\text { Fut } 7\end{array}$ & $\begin{array}{l}138.70 \\
204.38\end{array}$ & $0.000 *$ & $\begin{array}{l}157 \\
230\end{array}$ & $+46.49 \%$ & $0.000 *$ \\
\hline 8 & 0.399 & 0.600 & 0.0031 & $\begin{array}{l}\text { Hist8 } \\
\text { Fut } 8\end{array}$ & $\begin{array}{l}122.30 \\
121.37\end{array}$ & 0.963 & $\begin{array}{l}138.9 \\
140.3\end{array}$ & $+1.01 \%$ & 0.821 \\
\hline 9 & $0.000 *$ & 0.999 & 0.0479 & $\begin{array}{l}\text { Hist } 9 \\
\text { Fut } 9\end{array}$ & $\begin{array}{l}100.55 \\
121.77\end{array}$ & $0.000 *$ & $\begin{array}{l}116.1 \\
141.3\end{array}$ & $+21.7 \%$ & $0.000^{*}$ \\
\hline 10 & $0.000 *$ & 1.000 & 0.1273 & $\begin{array}{l}\text { Hist10 } \\
\text { Fut } 10\end{array}$ & $\begin{array}{l}167.35 \\
229.32\end{array}$ & $0.000 *$ & $\begin{array}{l}180 \\
251\end{array}$ & $+39.44 \%$ & $0.000^{*}$ \\
\hline 11 & 0.995 & $0.004 *$ & -0.0369 & $\begin{array}{l}\text { Hist11 } \\
\text { Fut } 11\end{array}$ & $\begin{array}{l}144.70 \\
122.00\end{array}$ & $0.001 *$ & $\begin{array}{l}164.7 \\
144.1\end{array}$ & $-12.51 \%$ & $0.003^{*}$ \\
\hline 12 & $0.000 *$ & 1.000 & 0.1642 & $\begin{array}{l}\text { Hist12 } \\
\text { Fut } 12\end{array}$ & $\begin{array}{l}119.75 \\
197.46\end{array}$ & $0.000 *$ & $\begin{array}{c}131.5 \\
226\end{array}$ & $+71.86 \%$ & $0.000^{*}$ \\
\hline 13 & $0.000 *$ & 0.999 & 0.0515 & $\begin{array}{l}\text { Hist13 } \\
\text { Fut } 13\end{array}$ & $\begin{array}{l}103.10 \\
128.94\end{array}$ & $0.000 *$ & $\begin{array}{l}120.4 \\
148.6\end{array}$ & $+23.42 \%$ & $0.000^{*}$ \\
\hline 14 & $0.000 *$ & 1.000 & 0.1186 & $\begin{array}{l}\text { Hist14 } \\
\text { Fut } 14\end{array}$ & $\begin{array}{l}134.15 \\
201.88\end{array}$ & $0.000 *$ & $\begin{array}{c}148.8 \\
218\end{array}$ & $+46.5 \%$ & $0.000^{*}$ \\
\hline 15 & $0.000 *$ & 1.000 & 0.1641 & $\begin{array}{l}\text { Hist15 } \\
\text { Fut } 15\end{array}$ & $\begin{array}{l}122.10 \\
212.52\end{array}$ & $0.000 *$ & $\begin{array}{c}139.5 \\
235\end{array}$ & $+68.46 \%$ & $0.000^{*}$ \\
\hline 16 & 0.451 & 0.549 & 0.0018 & $\begin{array}{l}\text { Hist16 } \\
\text { Fut } 16\end{array}$ & $\begin{array}{l}133.20 \\
121.85\end{array}$ & 0.508 & $\begin{array}{l}151 \\
147\end{array}$ & $-2.65 \%$ & 0.551 \\
\hline 17 & $0.000 *$ & 1.000 & 0.1612 & $\begin{array}{l}\text { Hist } 17 \\
\text { Fut } 17\end{array}$ & $\begin{array}{c}93.55 \\
183.20\end{array}$ & $0.000 *$ & $\begin{array}{c}114.5 \\
206\end{array}$ & $+79.91 \%$ & $0.000^{*}$ \\
\hline 18 & $0.000 *$ & 1.000 & 0.1372 & $\begin{array}{l}\text { Hist18 } \\
\text { Fut } 18\end{array}$ & $\begin{array}{l}112.65 \\
193.35\end{array}$ & $0.000 *$ & $\begin{array}{c}128.4 \\
202\end{array}$ & $+57.32 \%$ & $0.000^{*}$ \\
\hline 19 & $0.000 *$ & 0.999 & 0.0443 & $\begin{array}{l}\text { Hist19 } \\
\text { Fut } 19\end{array}$ & $\begin{array}{l}110.65 \\
121.61\end{array}$ & $0.011 *$ & $\begin{array}{l}123.5 \\
142.6\end{array}$ & $+15.46 \%$ & $0.003^{*}$ \\
\hline 20 & $0.009 *$ & 0.991 & 0.0319 & $\begin{array}{l}\text { Hist20 } \\
\text { Fut } 20\end{array}$ & $\begin{array}{l}112.70 \\
119.89\end{array}$ & 0.063 & $\begin{array}{l}129.1 \\
142.8\end{array}$ & $+10.61 \%$ & $0.043^{*}$ \\
\hline 21 & $0.000 *$ & 0.999 & 0.0428 & $\begin{array}{l}\text { Hist21 } \\
\text { Fut } 21\end{array}$ & $\begin{array}{l}100.80 \\
121.83\end{array}$ & $0.001 *$ & $\begin{array}{l}116.9 \\
139.3\end{array}$ & $+19.16 \%$ & $0.000^{*}$ \\
\hline 22 & 0.064 & 0.935 & 0.0192 & $\begin{array}{l}\text { Hist22 } \\
\text { Fut } 22\end{array}$ & $\begin{array}{l}120.50 \\
121.38\end{array}$ & 0.514 & $\begin{array}{l}129.4 \\
137.9\end{array}$ & $+6.57 \%$ & 0.164 \\
\hline 23 & $0.000^{*}$ & 1.000 & 0.1896 & $\begin{array}{l}\text { Hist23 } \\
\text { Fut } 23\end{array}$ & $\begin{array}{l}101.15 \\
197.23\end{array}$ & $0.000 *$ & $\begin{array}{c}113.8 \\
216\end{array}$ & $+89.81 \%$ & $0.000^{*}$ \\
\hline 24 & $0.000^{*}$ & 1.000 & 0.0794 & $\begin{array}{l}\text { Hist24 } \\
\text { Fut } 24\end{array}$ & $\begin{array}{l}115.70 \\
152.82\end{array}$ & $0.000 *$ & $\begin{array}{l}129.0 \\
164.3\end{array}$ & $+27.36 \%$ & $0.000^{*}$ \\
\hline
\end{tabular}

* Statistically significant trends at the 5\% significance level. 
A study by Cera and Ferraz (2015) analyzed precipitation trends in Rio Grande do Sul for three sets of data, with a comparison of the observed precipitation data (1982-2006) and simulated data by RegCM3 Regional Model (2070-2086) also showed an increasing trend for that State. They applied the Run test and Pettit test to certify the homogeneity of data for the series 1982 to 2006; but the tests gave different results and the Mann-Kendall test was used and this confirmed the Pettit test, indicating an increased trend of precipitation at a significant level of $99 \%$ in extreme north and central areas of the State of Rio Grande do Sul. The same study also analyzed the trend for future climate and the increase in precipitation trend at a $90 \%$ level of significance in the western, southern and central state was observed.

Other research similar to the study above was that of Doyle et al. (2012) in the La Plata Basin (LPB), where the northern part of this basin includes the State of Paraná. They employed the PRECIS regional climate modeling system for the annual rainfall and used precipitation data in the recent past (1961-1990) and in a future (2071-2100) climate at 5 and 10\% confidence levels and all stations showed positive trends with the values exceeding $8 \mathrm{~mm} \mathrm{yr}^{-1}$ over southern Brazil. For that same location, Marengo et al. (2012) made use of the Eta/HadCM3 Model configured with a 40-km grid size and was run over 1961 to 1990 to represent baseline climate, and 2011 to 2100 to simulate possible future changes. They detected a rainfall increase in the South East of South America (by about 30-50\%).

According to PBMC (2013), in southern Brazil and northern Argentina, trends for increased rainfall and river flows have been observed since the mid-twentieth century, with Paraná and La Plata Rivers showing a downward trend from 1901 to 1970 and a systematic increase in flows from the early 1970s to the present. It is also claimed that Southern region disasters such as landslides, death by drowning and building collapses may be more frequent. Agriculture and livestock in the region are vulnerable to climate change. There are numerous records of the El Niño Southern Oscillation (ENSO) phenomenon, which accentuates the conditioning/adversity features of the climate on agricultural production, determining production records or widespread losses. It should be added to the weather condition already affected by the ENSO, records of air temperature increase in various municipalities of Rio Grande do Sul, Santa Catarina and Paraná, which inevitably influence not only the agriculture and food security, but environmental conditions such as the hydrologic cycle and population health. Increases in rainfall and river flow, despite the uncertainties, are likely to intensify, as projected by the IPCC scenarios (IPCC, 2014). Temperatures will follow the pattern of increase in average values, with reduced episodes of frosts and cold days.

The location of points and the direction of trends for monthly precipitation data series during the period 1980 to 2050 are shown in Figure 3. Significant increasing trends were found in almost all the Mesoregions for the State of Paraná, except in West and West Central, where there wasn't any trend. In the South West and South Central, two points were detected for decreasing trend, but increasing trends also were found. This result is similar to that obtained by Zandonadi and Acquaotta (2016) for Paraná State: both results exhibited an increasing trend in the region of Curitiba (located in Metropolitan Curitiba), Castro (located in East Central), Irati (located in South East), Maringá and Londrina (both located in North Central), but differ in Campo Mourão region (located in West Central), where this study didn't show a trend and the other showed decreased trend. 


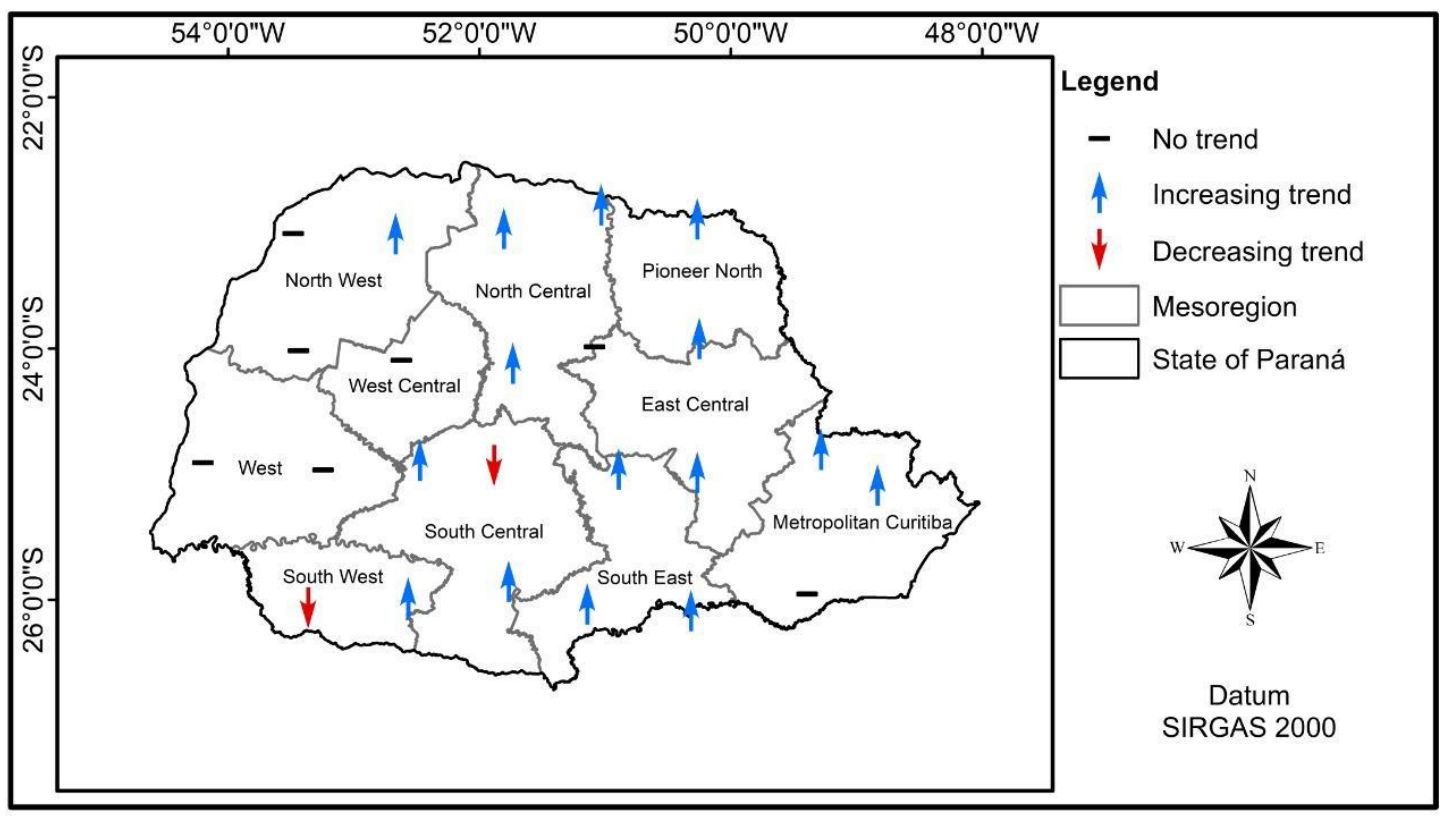

Figure 3. Spatial distribution of precipitation stations with increasing, decreasing and no trends during the period 1980 to 2050 .

The Figure 4 shows the monthly precipitation of seventeen points where there is trend increasing and decreasing the values. A large variability in monthly precipitation accumulation in graphics is observed, for instance, in Figure $4 \mathrm{j}$, where the maximum value of monthly accumulation reaches approximately $1000 \mathrm{~mm}$, whereas the graphic of Figure 4o) reaches 500 $\mathrm{mm} / \mathrm{month}^{-1}$. The red line confirms the trend displayed in Table 2 and adrees with Grimm et al. (2000), that say that in South Brazil there are seasonal characteristics of rainfall that can change when there is the El Niño/La Niña, causing extreme precipitation events as excess or deficit.

Observe the high variability between each month in Figure 4. In Figure 4b), the average of the historical series is $169 \mathrm{~mm} \mathrm{month}^{-1}$ and the mean in the simulated series is $227 \mathrm{~mm} \mathrm{month}{ }^{-1}$. This represents an increase of $34.32 \%$. In the time series of graphic Figure 4k), the means are 114.5 and $206 \mathrm{~mm} \mathrm{month}^{-1}$, an increase of $79.91 \%$. The same happens in the graphic of Figure 41), a rain increase of $57.32 \%$. According to Table 2, the maximum increment $(89.81 \%)$ is in Figure $4 p$ ), and the maximum reduction (19.66\%) in Figure 4a). Thus, if materializing expectations of these increases, there may be positive and negative impacts. An example of a positive impact is the replenishment of groundwater and an example of a negative impact is the increase of floods.

\section{CONCLUSIONS}

Considering the historical series (1980-2010) with the simulated series (2016-2050) that was simulated by the Eta/MIROC5 at twenty-four points, monthly precipitation showed increasing trends at fifteen locations in the State of Paraná and two sites showed a decrease in the monthly rainfall trend.

In some places, there is a big difference between the average monthly precipitation of 1980 to 2010 compared with the average expected precipitation of 2016 to 2050 .

The results also exhibited great variability in monthly rainfall for both the historical series and the simulated series. 
a)

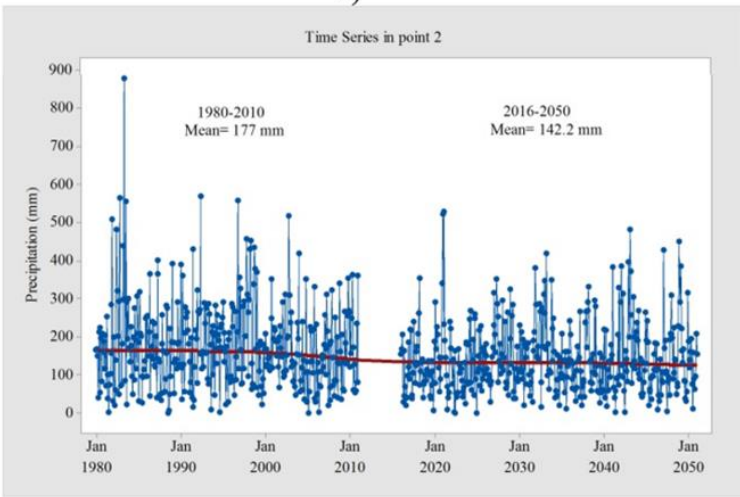

c)

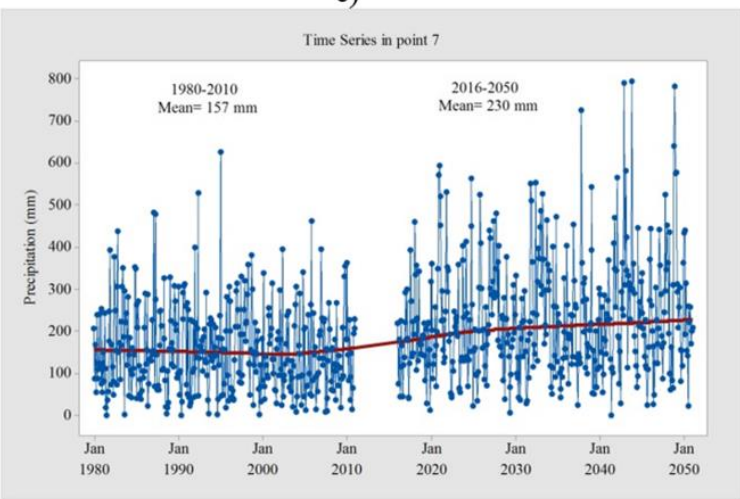

e)

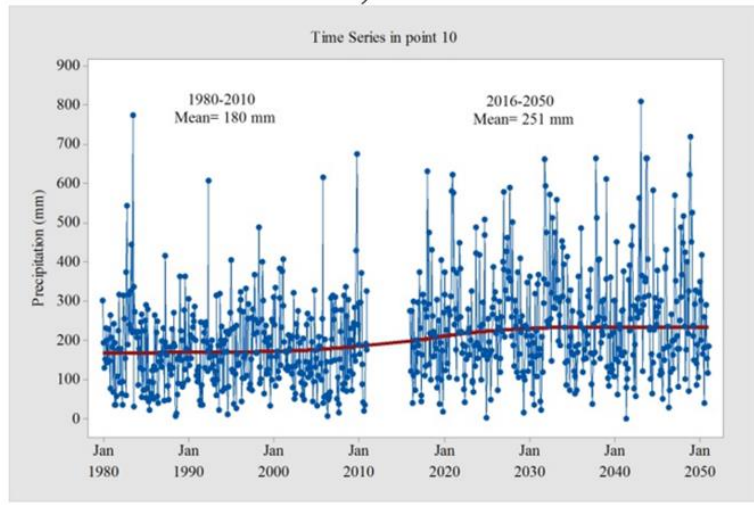

g)

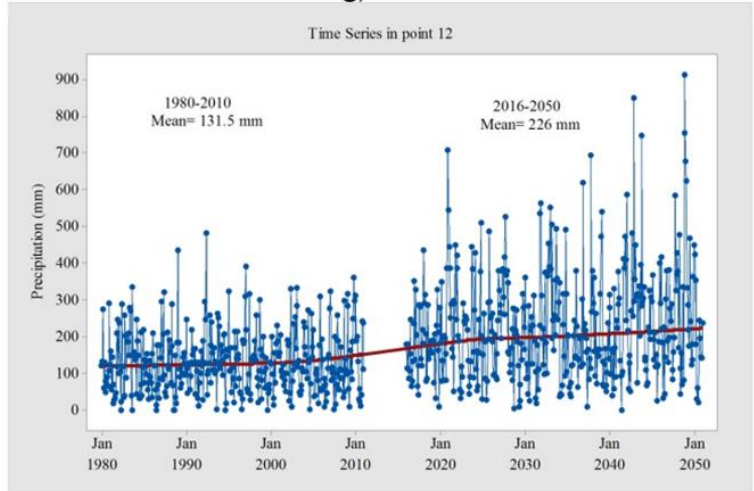

b)

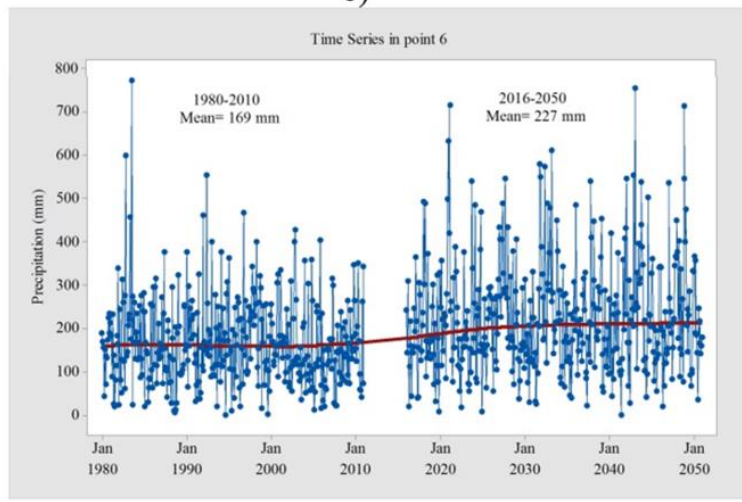

d)

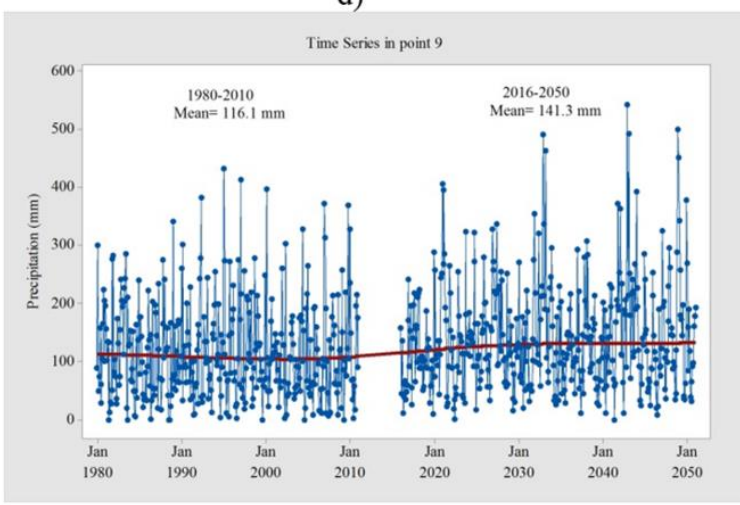

f)

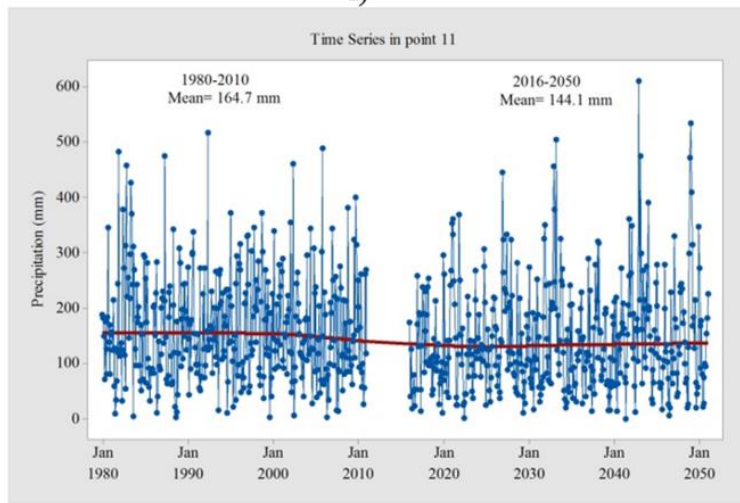

h)

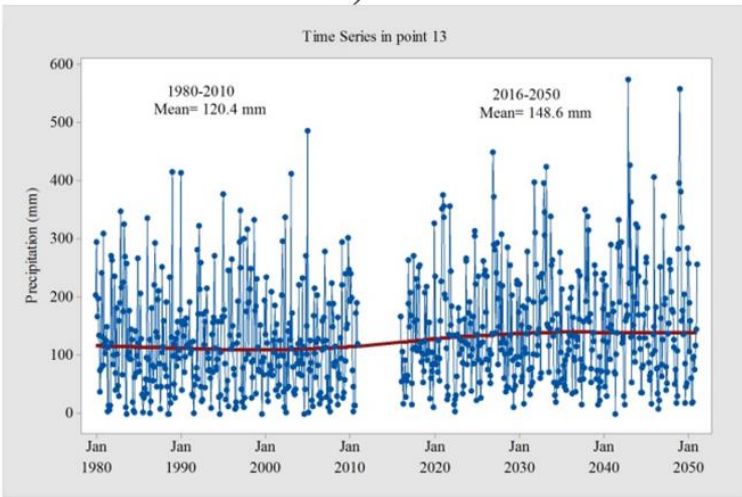

Figure 4. Temporal variation at points where show changes in precipitation trends during the period 1980-2050, along with the mean of historical and simulated precipitation. Continue. 


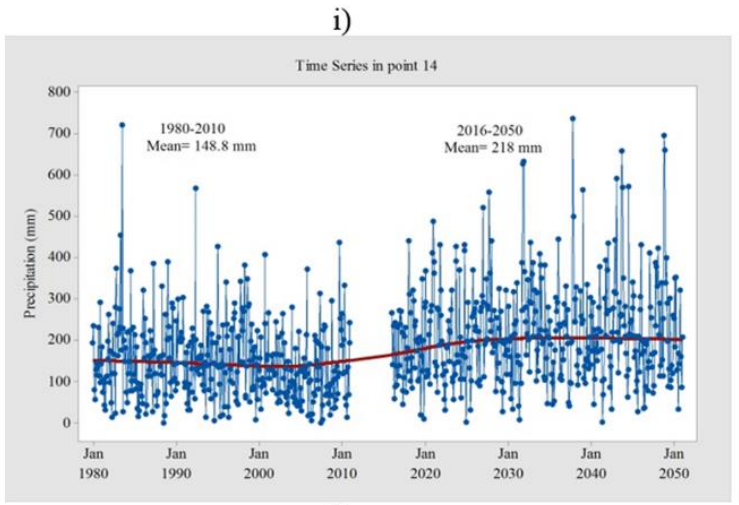

k)

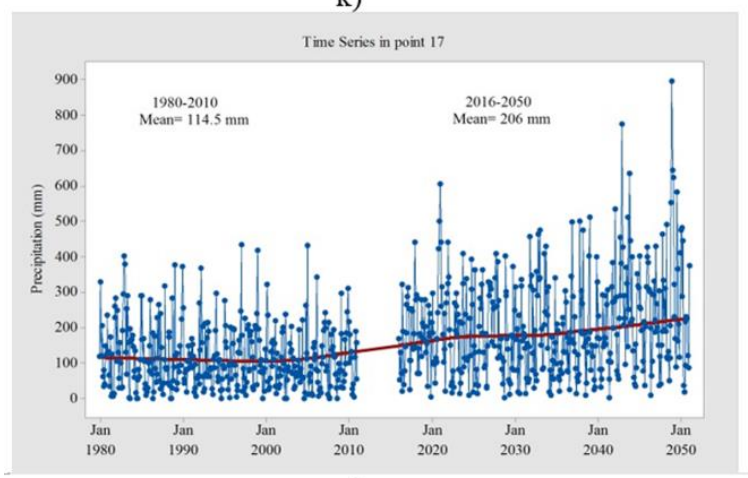

m)

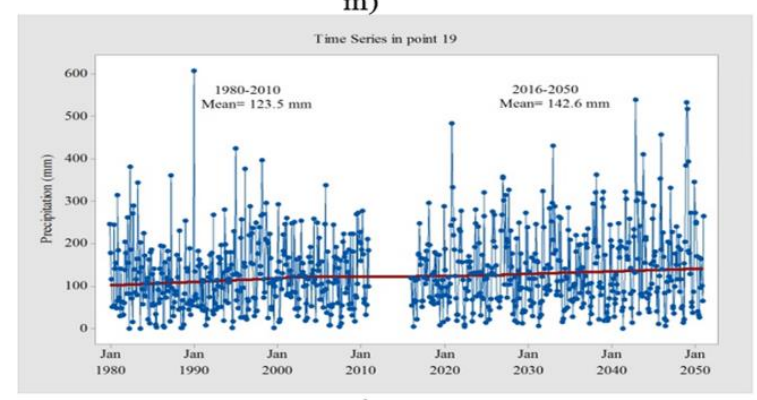

o)

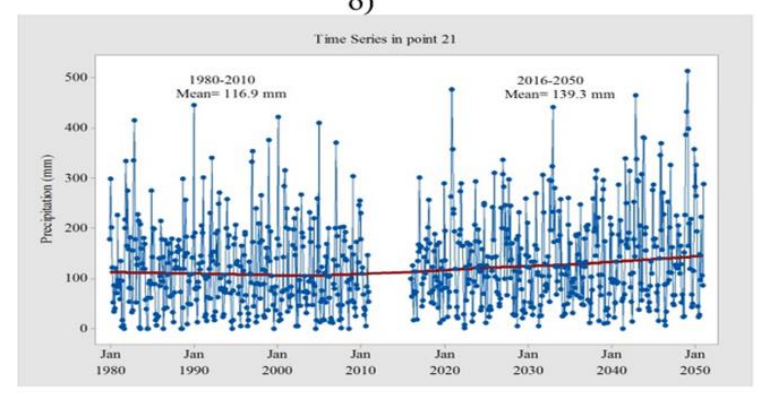

j)
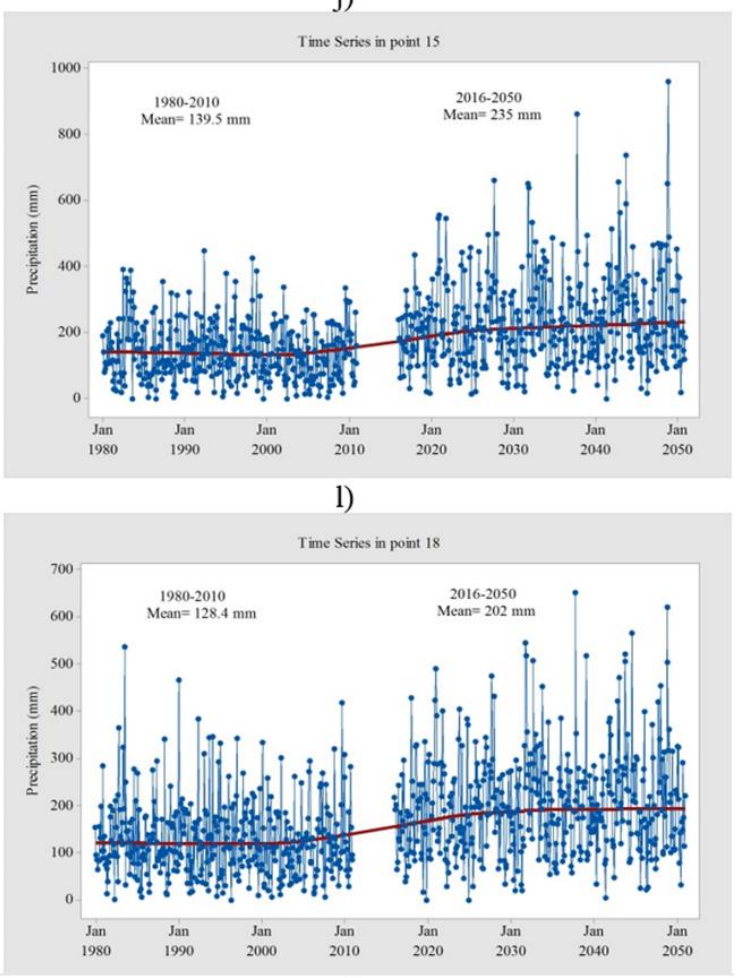

n)

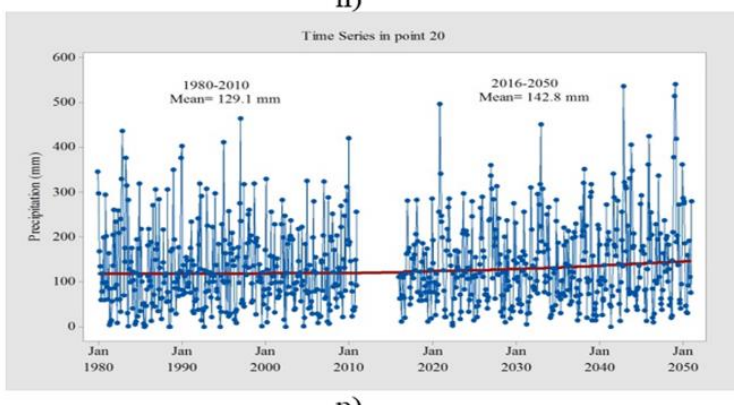

p)

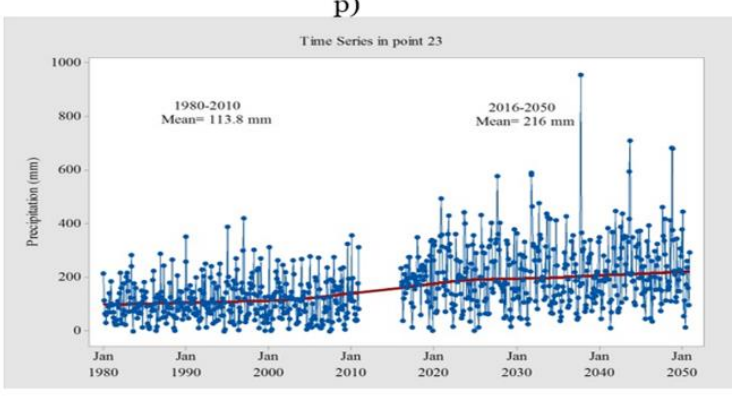

q)

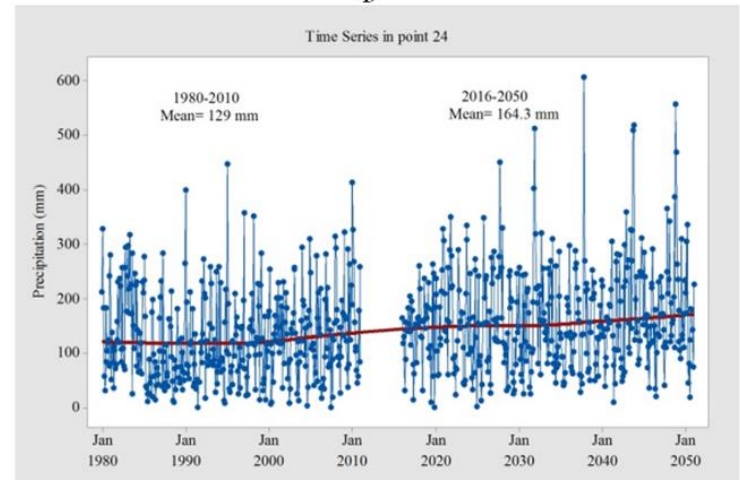

Figure 4. Continued. 


\section{REFERENCES}

ADAM, K. N.; COLliSCHONN, W. Análise dos impactos de mudanças climáticas nos regimes de precipitação e vazão na bacia hidrográfica do rio Ibicuí. Revista Brasileira de Recursos Hídricos, v. 18, n. 3, p. 69-79, 2013. http://dx.doi.org/10.21168/rbrh.v18n3.p69-79

BABA, R. K.; VAZ, M. S. M. G.; COSTA, J. D. Correção de dados agrometeorológicos utilizando métodos estatísticos. Revista Brasileira de Meteorologia, v. 29, n.4, p. 515526, 2014. http://dx.doi.org/10.1590/0102-778620130611

BARBOSA, S. E. S.; BARBOSA JÚNIOR, A. R.; SILVA, G. Q.; CAMPOS, E. N. B.; RODRIGUES, V.C. Geração de modelos de regionalização de vazões máximas, médias de longo período e mínimas de sete dias para a Bacia do Rio do Carmo, Minas Gerais. Revista Engenharia Sanitária e Ambiental, v. 10, n. 1, p. 64-71, 2005. http://dx.doi.org/10.1590/S1413-41522005000100008

CERA, J. C.; FERRAZ, S. E. T. Variações climáticas na precipitação no sul do Brasil no clima presente e futuro. Revista Brasileira de Meteorologia, v. 30, n.1, p. 81-88, 2015. http://dx.doi.org/10.1590/0102-778620130588

CHOU, S. C.; MARENGO, J. A.; LYRA, A. A.; SUEIRO, G.; PESQUERO, J. F.; ALVES, L. M.; KAY, G.; BETTS, R.; CHAGAS, D. J.; GOMES, J. L.; BUSTAMANTE, J. F.; TAVARES, P. Downscaling of South America present climate driven by 4-member HadCM3 runs. Journal Climate Dynamics, v. 38, p. 635-653, 2011. http://dx.doi.org/10.1007/s00382-011-1002-8

DOYLE, M. E.; SAURRAL, R. I.; BARROS, V. R. Trends in the distributions of aggregated monthly precipitation over the La Plata Basin. International Journal of Climatology, $\mathrm{v}$. 32, n. 14, p. 2149-2162, 2012. http://dx.doi.org/10.1002/joc.2429

GIAROLLA, A.; RESENDE, N.; CHOU, S. C.; TAVARES, P. S.; RODRIGUES, D. C. Coffee beverage quality assessment based on Eta/CPTEC-HadCM3 model (A1B-IPCC/SRES scenario), Southeastern Brazil. Geophysical Research Abstracts, v. 14, n. 1, p. 6224, 2012.

GOCIC, M.; TRAJKOVIC, S. Analysis of changes in meteorological variables using MannKendall and Sen's slope estimator statistical tests in Serbia. Global and Planetary Change, v.100, p. 172-182, 2013. http://dx.doi.org/10.1016/j.gloplacha.2012.10.014

GRIMM, A. M.; BARROS, V. R.; DOYLE, M. E. Climate Variability in Southern South America Associated with El Niño and La Niña Events. Journal of Climate, v. 13, p. 3558, 2000. https://doi.org/10.1175/1520-0442(2000)013\%3C0035:CVISSA\%3E2.0.CO;2

IPCC. Climate change 2014: mitigation of climate change. Contribution of working group III. Cambridge: Cambridge University Press, 2014.

KIM, D. W.; DEO, R. C.; CHUNG, J. H.; LEE, J. S. Projection of heat wave mortality related to climate change in Korea. Natural Hazards, v. 80, p. 623-637, 2016. http://dx.doi.org/10.1007/s11069-015-1987-0 
MARENGO, J. A.; HOU, S. C.; KAY, G.; ALVES, L. M.; PESQUERO, J. F.; SOARES, W. R.; SANTOS, D. C.; LYRA, A. A.; SUEIRO, G.; BETTS, R.; CHAGAS, D. J.; GOMES, J. L.; BUSTAMANTE, J.; TAVARES, P. Development of regional future climate change scenarios in South America using the Eta CPTEC/HadCM3 climate change projections: climatology and regional analyses for the Amazon, São Francisco and the Paraná River basins. Climate Dynamics, v. 38, p. 1829-1848, 2012. http://dx.doi.org/10.1007/s00382011-1155-5

MARENGO, J. A.; JONES, R.; ALVES, L. M.; VALVERDE, M. C. Future Change of Temperature and Precipitation Extremes in South America as Derived from the PRECIS Regional Climate Modeling System. International Jounal of Climatology, v. 29, n. 15, p. 2241-2255, 2009. http://dx.doi.org/10.1002/joc.1863

PBMC. Executive Summary: Impacts, vulnerability and adaptation to climate change. Contribution from GT2 to the Primeiro Relatório de Avaliação Nacional sobre de Mudanças Climáticas (RAN1) of the painel brasileiro de mundança climática (PBMC). Rio de Janeiro: UFRJ, 2013. 28p.

PRUSKI, F. F.; PEREIRA, S. B.; NOVAES, L. F.; Silva, D. D.; Ramos, M. M. Precipitação média anual e vazão específica média de longa duração, na Bacia do São Francisco. Revista Brasileira de Engenharia Agrícola e Ambiental, v. 8, n. 2/3, p.2 47-253, 2004. http://dx.doi.org/10.1590/S1415-43662004000200013

SANTOS, M.; FRAGOSO, M. Precipitation variability in Northern Portugal: data homogeneity assessment and trends in extreme precipitation indices. Atmospheric Research, v. 131, p. 34-45, 2013. http://dx.doi.org/10.1016/j.atmosres.2013.04.008

SINGH, V.; GOYAL, M. K. Analysis and trends of precipitation lapse rate and extreme indices over north Sikkim eastern Himalayas under CMIP5ESM-2M RCPs experiments. $\begin{array}{llllll}\text { Atmospheric Research, } & \text { v. } & \text { 167, } & \text { p. }\end{array}$ http://dx.doi.org/10.1016/j.atmosres.2015.07.005

VUUREN, D P. V.; EDMONDS, J.; KAINUMA, M.; RIAHI, K.; THOMSON, A.; HIBBARD, K.; HURTT, G. C.; KRAM, T.; KREY, V.; LAMARQUE, J. F.; MASUI, T.; MEINSHAUSEN, M.; NAKICENOVIC, N.; SMITH, S. J.; ROSE, S. K. The representative concentration pathways: an overview. Climatic Change, v. 109, p. 5-31, 2011. http://dx.doi.org/10.1007/s10584-011-0148-z

YÜREKLI, K. Impact of climate variability on precipitation in the Upper Euphrates - Tigris Rivers Basin of Southeast Turkey. Atmospheric Research, v. 154, p. 25-38, 2015. http://dx.doi.org/10.1016/j.atmosres.2014.11.002

ZANDONADI, L.; ACQUAOTTA, F.; FRATIANNI, S.; ZAVATTINI, J. A. Changes in precipitation extremes in Brazil (Paraná River Basin). Theoretical and Applied Climatology, v. 123, p. 741-756, 2016. http://dx.doi.org/10.1007/s00704-015-1391-4 